\title{
Effects of two strains of the parasitic dinoflagellate Amoebophrya on growth, photosynthesis, light absorption, and quantum yield of bloom-forming dinoflagellates
}

\author{
Myung G. Park ${ }^{1, *}$, Sean K. Cooney ${ }^{1}$, Wonho Yih ${ }^{2}$, D. Wayne Coats ${ }^{1}$ \\ ${ }^{1}$ Smithsonian Environmental Research Center, PO Box 28, Edgewater, Maryland 21037, USA \\ ${ }^{2}$ Department of Oceanography, Kunsan National University, San 68, Miryong-dong, Kunsan, 573-701, Korea
}

\begin{abstract}
Eukaryotic parasites are believed to play important roles in bloom dynamics of red-tide dinoflagellates; however, little is known about their impact on host physiology and behavior. To address those issues, we examined the influence of parasitic dinoflagelates, Amoebophrya spp., on growth, photosynthesis, light absorption, and quantum yield of the bloom-forming dinoflagellates Akashiwo sanguinea and Gymnodinium instriatum. Parasites of the 2 host species differed in their site of infection, developing in the nucleus of $A$. sanguinea but in the cytoplasm of $G$. instriatum, and had divergent effects on host photophysiology. Neither host species appeared competent to reproduce once infected, as growth of fully infected populations was negligible and cell division of infected hosts was never observed. Uninfected populations of both host species exhibited strong diel periodicity in photosynthesis, with parasitized cultures showing distinctly different patterns. Infected $A$. sanguinea displayed little or no photosynthetic periodicity, whereas diel periodicity continued in parasitized G. instriatum but was less pronounced than that of uninfected host. Chlorophyll a (chl a) content of A. sanguinea declined steadily over the infection cycle, while per cell and per chl a photosynthetic rates decreased sharply until $16 \mathrm{~h}$ and then stabilized at $\sim 50 \mathrm{pgC} \mathrm{cell}{ }^{-1} \mathrm{~h}^{-1}$ and $\sim 1 \mathrm{mgC}$ $(\mathrm{mg} \mathrm{chl} a)^{-1} \mathrm{~h}^{-1}$, respectively. By comparison, chl a content of infected G. instriatum was comparable with that of uninfected cells, with photosynthetic performance remaining high $(\sim 80 \%$ of uninfected hosts) until very late in the infection cycle. Light absorption by hosts increased in the blue region and decreased in the red region of the spectrum during the infection cycle, consequently enhancing chl $a-$ specific absorption coefficients relative to uninfected cells by as much as 22 to $56 \%$ for A. sanguinea and $59 \%$ for G. instriatum. Furthermore, parasitism lowered maximum quantum yields in photosynthesis of both hosts by a factor of $\sim 2$, particularly in late infection stages. The contrasting effects of intranuclear and intracytoplasmic strains of Amoebophrya on photosynthetic performances and photophysiological properties of host cells suggest that these parasites may exert somewhat different influences on primary production and microbial activities during epidemic outbreaks in natural systems.
\end{abstract}

KEY WORDS: Parasitism · Photosynthesis · Light absorption · Quantum yield · Akashiwo sanguinea · Gymnodinium instriatum $\cdot$ Red tide

Resale or republication not permitted without written consent of the publisher

\section{INTRODUCTION}

Globally increasing frequency, magnitude, and impacts of harmful algal blooms (HABs) (Hallegraeff 1993)

\footnotetext{
*Present address: Red Tide Research Center, Kunsan National University, Kunsan, 573-701, Korea.

E-mail: myungpark@kunsan.ac.kr
}

have stimulated considerable interest in biological methods to control bloom-forming species (Anderson 1997). Algal viruses (Bratbak et al. 1993, 1995, Milligan \& Cosper 1994, Nagasaki et al. 1994a, b, 1999, Nagasaki \& Yamaguchi 1997, Brussaard et al. 1999, Tarutani et al. 2000), algicidal bacteria (Fukami et al. 1991, 1992, Imai et al. 1993, Doucette 1995, Lovejoy et al. 1998, Doucette et al. 1999), protozoan grazers (Naka- 
mura et al. 1995, Kamiyama 1997, Jeong et al. 1999a,b, Matsuyama et al. 1999), and eukaryotic parasites including fungi and certain flagellates (Taylor 1968, Bruning et al. 1992, Coats 1999, Norén et al. 1999, ErardLe Denn et al. 2000) all have the potential to exert controlling influences on HAB species.

Algal viruses, including those infecting $\mathrm{HAB}$ and non-HAB species, have received more attention from the standpoint of their ecophysiological impacts and biogeochemical roles than have other microparasites. For example, algal photosynthetic rates can be reduced by as much as $78 \%$ during viral infection; however, in some cases, photosynthesis is not strongly inhibited or not affected until near the onset of cell lysis (Suttle et al. 1990, Suttle 1992, Suttle \& Chan 1993). Further, algal virus can contribute significantly to the flux of energy and matter, influencing biogeochemical cycling of carbon, nitrogen, and sulfur (Gobler et al. 1997, Hill et al. 1998). Similar data are not available for algicidal bacteria or eukaryotic parasites of algae.

Parasitic dinoflagellates have long been thought to have a significant influence on the ecology of bloomforming dinoflagellates (for review, see Coats 1999). Species of Amoebophrya are particularly noteworthy, as they are widely distributed in coastal environments and have been reported from numerous host species (Cachon 1964, Taylor 1968, Elbrächter 1973, Nishitani et al. 1985, Cachon \& Cachon 1987, Fritz \& Nass 1992, Coats \& Bockstahler 1994, Coats et al. 1996). Amoebophrya spp. prevent reproduction of their hosts (Elbrächter 1973), have relatively short generation times (Coats \& Bockstahler 1994), and have a simple life cycle that culminates in death of the host (Cachon 1964), all of which make these parasites likely candidates for controlling host populations. The life cycle of Amoebophrya spp. includes a free-swimming infective stage (the dinospore) that attaches to the host and penetrates through the host cell membrane, a growth phase (trophont) inside the host cell, and a multinucleate, multiflagellate stage (the vermiform) that is released upon death of the host and undergoes cytokinesis to yield hundreds to thousands of dinospores.

Amoebophrya spp. appear well adapted to exploit host populations in enriched coastal settings (Yih \& Coats 2000); however, infection levels are highly variable, ranging from $<1$ to $80 \%$ (Taylor 1968, Elbrächter 1973, Nishitani \& Chew 1984, Nishitani et al. 1984, 1985, Fritz \& Nass 1992, Coats \& Bockstahler 1994, Coats et al. 1996). Furthermore, estimates of host mortality resulting from Amoebophrya infections range from a maximum of $8 \%$ daily in the mainstem of Chesapeake Bay (Coats \& Bockstahler 1994) to $54 \%$ daily in a shallow subestuary of the bay (Coats et al. 1996). Parasitism may also alter host physiology in ways that influence rates of primary production or release of dissolved organic compounds, but those processes have not been addressed previously.

The current study was undertaken to test the hypothesis that parasitism by Amoebophrya spp. alters host photosynthetic performance and photophysiological properities. To test this hypothesis, we determined photosynthetic rates, photosynthesis-irradiance (P-E) parameters, light absorption coefficient, and maximum quantum yield of photosynthesis for infected and uninfected cultures of 2 different host-parasite systems. Both systems were isolated from Chesapeake Bay, with one being Amoebophrya sp. ex Akashiwo sanguinea (= Gymnodinium sanguineum) and the other Amoebophrya sp. ex Gymnodinum instriatum (previously Gyrodinium instriatum). The former is the same parasite referred to as A. ceratii (Coats \& Bockstahler 1994), A. ceratii ex Gymnodinium sanguineum (Coats et al. 1996), and Amoebophrya sp. ex Gymnodinium sanguineum (Gunderson et al. 1999, Yih \& Coats 2000), while the latter is a new strain isolated from the Rhode River subestuary of Chesapeake Bay.

\section{MATERIALS AND METHODS}

Cultures. Chesapeake Bay isolates of Akashiwo sanguinea, Gymnodinium instriatum, and their corresponding strains of Amoebophrya spp. were maintained as stock cultures in $\mathrm{f} / 2-\mathrm{Si}$ medium (Guillard \& Ryther 1962) formulated using 15\% Chesapeake Bay water plus soil extract ( $5 \% \mathrm{v} / \mathrm{v})$. Parasites were propagated by sequentially transferring aliquots of infected A. sanguinea and $G$. instriatum into uninfected host cultures at 2 to $3 \mathrm{~d}$ intervals. Stock and experimental cultures were not axenic and were maintained at $20^{\circ} \mathrm{C}$ under a 14:10 light:dark cycle of cool-white fluorescent light at an irradiance of $175 \mu \mathrm{mol}$ photons $\mathrm{m}^{-2} \mathrm{~s}^{-1}$ for A. sanguinea and $95 \mu \mathrm{mol}$ photons $\mathrm{m}^{-2} \mathrm{~s}^{-1}$ for $G$. instriatum.

Experiments were conducted in duplicate using stock cultures of Akashiwo sanguinea and Gymnodinium instriatum in exponential growth. Infected treatments consisted of host stocks inoculated with recently formed ( $\leq 6 \mathrm{~h}$ old) dinospores of Amoebophrya spp. to yield near $100 \%$ infection levels. To accomplish this, recently formed dinospores were harvested by gravity filtration of stock host-parasite cultures using Nuclepore filters with a pore size of $12 \mu \mathrm{m}$ for $A$. sanguinea and $8 \mu \mathrm{m}$ for $G$. instriatum. Subsamples were fixed with $\mathrm{CaCO}_{3}$-buffered formalin (1\% final conc.) and dinospore abundance was determined using a hemocytometer and a Zeiss Axioscope $(\times 200)$ equipped with epifluorescence microscopy (450 to $490 \mathrm{~nm}$ excitation; $520 \mathrm{~nm}$ barrier filter) for distinguishing the green autofluorescence of the parasites (Coats \& Bock- 
stahler 1994). Aliquots of harvested dinospores were then added to host cultures to give a dinospore:host ratio of 20:1 for A. sanguinea and $80: 1$ or 100:1 for $G$. instriatum. Uninfected controls consisted of host cultures inoculated with equivalent volumes of harvested dinospore filtrate (Whatman GF/F).

Growth, chlorophyll a content, and photosynthesis over diel cycle. Four flasks containing 300 to $400 \mathrm{ml}$ of culture at $\sim 1 \times 10^{3}$ cells ml ${ }^{-1}$ were established for each host species. At CT 4 (circadian time: time corresponding to hour after the onset of the light period), 2 flasks of Akashiwo sanguinea and 2 flasks of Gymnodinium instriatum were inoculated with dinospores of the corresponding parasite, while the remaining flasks received equivalent volumes of dinospore filtrate. Subsamples for measuring host density, parasite prevalence, chlorophyll a (chl a) concentration, and host photosynthetic rate were taken from treatments and controls following inoculation and at $8 \mathrm{~h}$ intervals over the following $72 \mathrm{~h}$ for $A$. sanguinea and $56 \mathrm{~h}$ for $G$. instriatum.

At each sampling period, a $7.5 \mathrm{ml}$ aliquot from each flask was preserved with modified Bouin's solution (Coats \& Heinbokel 1982) for estimating host abundance, and a set of $1 \mathrm{ml}$ subsamples was preserved with $\mathrm{CaCO}_{3}$-buffered formalin (1\% final conc.) for determining parasite prevalence. Estimates of host abundance were obtained by enumerating cells present in microscope transects $(\times 10)$ of triplicate Sedgwick-Rafter chambers. For each chamber, successive transects were examined until 100 cells had been counted or 5 transects (half the chamber area) had been scanned. Parasite prevalence was determined by scoring 100 cells as uninfected or infected hosts using epifluorescence microscopy to detect the green-fluorescing trophonts of Amoebophrya spp.

To determine chl a concentration, $5 \mathrm{ml}$ samples were concentrated onto $25 \mathrm{~mm}$ Whatman GF/C filters and the chl a was extracted for $24 \mathrm{~h}$ in the dark using $90 \%$ acetone at $4^{\circ} \mathrm{C}$. Chl a concentration was determined fluorometrically using a Turner Designs 10-AU fluorometer and normalized to host density to give cellular chl a content.

For measurement of photosynthesis, $1 \mathrm{ml}$ aliquots from each flask were distributed to five $7 \mathrm{ml}$ scintillation vials, two of which were wrapped with aluminum foil to serve as dark controls. Vials were spiked with $\mathrm{NaH}^{14} \mathrm{CO}_{3}$ (ICN Chemicals) to a final activity of $0.25 \mu \mathrm{Ci} \mathrm{ml}^{-1}\left(=9.3 \mathrm{kBq} \mathrm{ml}^{-1}\right)$ and incubated for $1 \mathrm{~h}$ at growth irradiance (see above). Incubations were terminated by adding $0.25 \mathrm{ml}$ of $10 \% \mathrm{HCl}$ to each vial, and the vials were then placed on an orbital shaker (150 rpm) for ca $8 \mathrm{~h}$ at room temperature to remove inorganic ${ }^{14} \mathrm{C}$. Ecolume scintillation cocktail $(5 \mathrm{ml})$ was added to each vial and radioactivity determined using a liquid scintillation counter (Packard Instrument TriCarb model 1600TR). Total dissolved $\mathrm{CO}_{2}$ in the media was measured by a Capni-Con (Cameron Instrument) 5 total carbon dioxide analyzer. Total activity of the $\mathrm{NaH}^{14} \mathrm{CO}_{3}$ was determined from $20 \mu \mathrm{l}$ aliquots of working ${ }^{14} \mathrm{C}$-stock solution placed directly into triplicate vials containing $200 \mu \mathrm{l}$ phenethylamine plus $5 \mathrm{ml}$ scintillation cocktail. The ${ }^{14} \mathrm{C}$ activity of dark controls was subtracted from that of the light bottles, and photosynthetic rate was calculated according to Parsons et al (1984). Photosynthetic rate (P) was then normalized to chl a concentration and cell number to yield chl aspecific ( $\left.\mathrm{P}^{\mathrm{chl}} ; \mathrm{mgC} \mathrm{mg} \mathrm{chl} a^{-1} \mathrm{~h}^{-1}\right)$ and cell-specific ( $\mathrm{P}^{\text {cell }}$; pgC cell ${ }^{-1} \mathrm{~h}^{-1}$ ) rates.

Parameters of the P-E curve. P-E curves were obtained in a separate experiment that was set up following the protocol described above. Experimental and control flasks were inoculated with dinospores and dinospore filtrate, respectively, at CT 3.5 for Akashiwo sanguinea and CT 5.5 for Gymnodinium instriatum. Subsamples were taken for determination of P-E curves after $1 \mathrm{~h}$ (CT 4.5), $24.5 \mathrm{~h}$ (CT 4) and $50.5 \mathrm{~h}$ (CT 6) for $A$. sanguinea and after $1 \mathrm{~h}$ (CT 6.5), $25 \mathrm{~h}$ (CT 6.5) and $46.5 \mathrm{~h}$ (CT 4) for G. instriatum.

Data for P-E curves were obtained from temperature-controlled photosynthetron incubations using a modification of the protocol described by Lewis \& Smith (1983). At each sampling period, a $14 \mathrm{ml}$ subsample from each flask was spiked with $\mathrm{NaH}^{14} \mathrm{CO}_{3}$ to give a final activity of $0.25 \mu \mathrm{Ci} \mathrm{m}^{-1}$ and then distributed as $1 \mathrm{ml}$ aliquots to 12 scintillation vials $(7 \mathrm{ml}$ capacity). One vial from each flask received 1 of 12 different light levels, ranging from $\sim 20$ to $\sim 1800 \mu \mathrm{mol}$ photons $\mathrm{m}^{-2} \mathrm{~s}^{-1}$. The different light levels were produced by reducing irradiance from a $250 \mathrm{~W}$ halogen lamp using neutral density screens. Light was measured with a quantum scalar sensor (Biospherical Instruments QSL-100) mounted inside a scintillation vial. The experiment included 2 dark controls per replicate. Total dissolved $\mathrm{CO}_{2}$ in the media, total activity of $\mathrm{NaH}^{14} \mathrm{CO}_{3}$, host cell density, chl a concentration, and parasite prevalence were determined as above. Incubations were terminated after $1 \mathrm{~h}$ and rates of photosynthesis were determined following procedures described above. $\mathrm{P}^{\text {chl }}$ and $\mathrm{P}^{\text {cell }}$ were fitted to a hyperbolic tangent function (Jassby \& Platt 1976) using TableCurve 2D 5.0 (SPSS Inc, Chicago, IL, USA) and used to determine photosynthetic efficiency (i.e., initial slope of the P-E curve; $\alpha^{\text {chl }}$ and $\alpha^{\text {cell }}$ ) and photosynthetic capacity $\left(\mathrm{P}_{\max }^{\mathrm{chl}}\right.$ and $\left.\mathrm{P}_{\max }^{\text {cell }}\right)$.

Light absorption. During the P-E curve experiment, $20 \mathrm{ml}$ subsamples from each flask were filtered through $25 \mathrm{~mm}$ Whatman GF/C filters. The filters were then scanned from 400 to $750 \mathrm{~nm}$ with a Cary 4 (Varian Australia Pty) dual beam spectrophotometer, using a 
blank filter wetted with GF/C filtrate as a control. Optical density of the filtered sample $\left[\operatorname{OD}_{\mathrm{f}}(\lambda)\right]$ at $750 \mathrm{~nm}$ was subtracted from the entire spectrum to correct for scattering (Bricaud \& Stramski 1990). The $\mathrm{OD}_{\mathrm{f}}(\lambda)$ was then corrected for pathlength-amplification factor using the quadratic equation proposed by Tassan \& Ferrari (1995) for optical density of cells in suspension $\left[\mathrm{OD}_{\mathrm{s}}(\lambda)\right]$. The $\mathrm{OD}_{\mathrm{s}}(\lambda)$ values were then converted to biomass $\left(B_{i}\right.$ chl a concentration or cell number)-normalized absorption coefficients, $a^{*}{ }_{B}(\lambda)$, as follows:

$$
a_{\mathrm{B}}^{*}(\lambda)=\frac{2.3 \mathrm{OD}_{\mathrm{S}}(\lambda)}{\mathrm{XB}}
$$

where 2.3 is a conversion factor from $\log _{10}$ to $\ln , \mathrm{X}$ is the geometrical path length (volume filtered divided by clearance area of the filter), and $B$ is as defined above. In this study, $a^{* \text { chl }}$ and $a^{* \text { cell }}$ are presented in units of $\mathrm{m}^{2}$ (mg chl $\left.a\right)^{-1}$ and $\mathrm{m}^{2}$ cell $^{-1}$, respectively.

Maximum quantum yield. Maximum quantum yield of photosynthesis [ $\phi_{\mathrm{m}}$ mol $\mathrm{C}$ (mol photons) $\left.{ }^{-1}\right]$ was calculated from the ratio of $\alpha^{\text {chl }}$ to mean $a^{* \text { chl }}$ (spectrally non-weighted, average specific absorption coefficient over the range 400 to $700 \mathrm{~nm}$ ), scaled by a constant of 0.02315 to convert grams of carbon to moles of carbon and hours to seconds.

Statistical analysis. Data are reported as mean \pm SE of the mean from duplicate incubation bottles unless otherwise stated. Data for uninfected controls and infected treatments were compared by Student's $t$-test using SigmaStat 2.0 (SPSS).

\section{RESULTS}

\section{Growth and cellular chl a content in infected and uninfected hosts}

Uninfected Akashiwo sanguinea and Gymnodinium instriatum showed steady growth during the experiment at rates of $0.12 \pm 0.001$ and $0.28 \pm 0.019 \mathrm{~d}^{-1}$, respectively, when calculated from linear regression of ln-transformed cell abundance versus elapsed time (Fig. 1A,C). By contrast, abundance of $A$. sanguinea and $G$. instriatum in parasitized cultures remained relatively constant until 48 and $40 \mathrm{~h}$, respectively, and then declined dramatically. Parasite prevalence in those cultures averaged $100 \%$ for $A$. sanguinea and $97 \%$ for $G$. instriatum. Site of infection differed between the 2 host species, with the parasites always developing in the nucleus of $A$. sanguinea but only in the cytoplasm of $G$. instriatum.

Chl a content of uninfected Akashiwo sanguinea was relatively constant at $54.3 \pm 0.89 \mathrm{pg} \mathrm{chl} \mathrm{a} \mathrm{cell}{ }^{-1}$, although there was some diel variation during the experiment, whereas chl a content of infected $A$. sanguinea gradually decreased at a rate of $-0.60 \pm 0.097 \mathrm{~h}^{-1}$ after $16 \mathrm{~h}$ (Fig. 1B). By comparison, chl a content (121.5 \pm $4.19 \mathrm{pg} \mathrm{chl} \mathrm{a} \mathrm{cell}{ }^{-1}$ ) of infected Gymnodinium instriatum was not significantly different ( $t$-test, p > 0.05) from that of uninfected $G$. instriatum $(122.5 \pm 7.31 \mathrm{pg}$ chl a cell ${ }^{-1}$ ) through the first $32 \mathrm{~h}$ of the experiment (Fig. 1D). After $32 \mathrm{~h}$, however, chl a content of infected

\section{A. sanguinea}
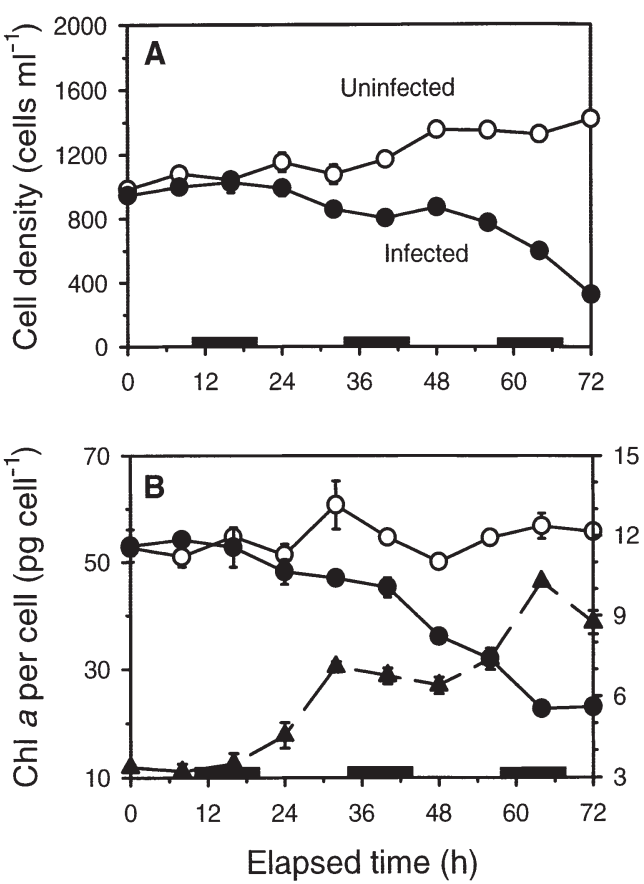

Elapsed time (h)

\section{G. instriatum}
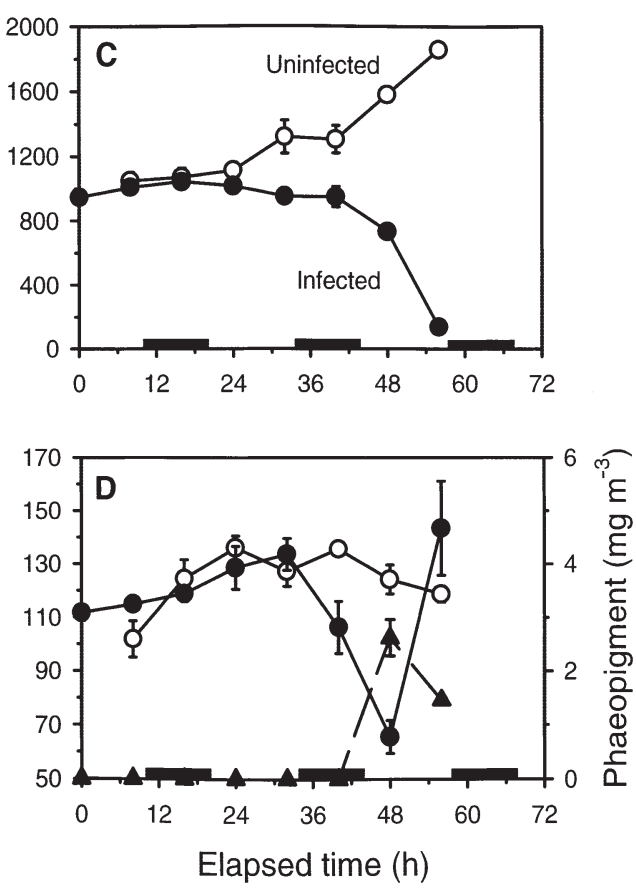

Fig. 1. Diel variations in $(A, C)$ cell density and $(\mathrm{B}, \mathrm{D})$ cellular content of chlorophyll (chl) $a$ in infected and uninfected cultures of (A,B) Akashiwo sanguinea and $(\mathrm{C}, \mathrm{D})$ Gymnodinium instriatum. Open and closed circles represent uninfected and infected cultures, respectively. Phaeopigment concentrations in infected cultures are represented by closed triangles. Dark bars on abscissa indicate the dark period. Data points represent mean \pm SE of the mean 
A. sanguinea
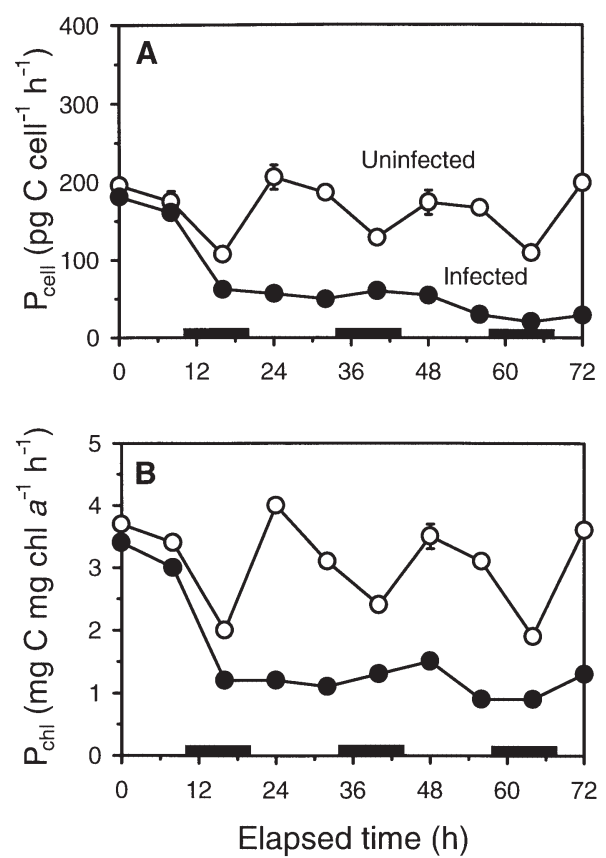

G. instriatum
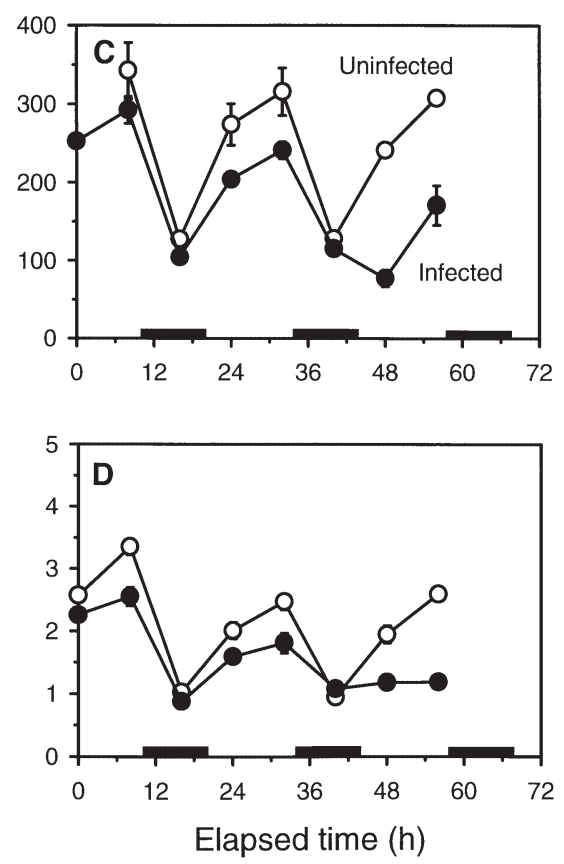

Fig. 2. Diel variations in $(\mathrm{A}, \mathrm{C})$ cell-specific $\left(\mathrm{P}^{\mathrm{cell}}\right)$ and $(\mathrm{B}, \mathrm{D}) \mathrm{chl}$ a-specific $\left(\mathrm{P}^{\mathrm{chl}}\right)$ rates of photosynthesis in infected and uninfected cultures of $(\mathrm{A}, \mathrm{B})$ Akashiwo sanguinea and $(\mathrm{C}, \mathrm{D})$ Gymnodinium instriatum. Open and closed circles represent uninfected and infected cultures, respectively. Dark bars on abscissa indicate the dark period. Data points represent mean $\pm \mathrm{SE}$ of the mean

G. instriatum declined dramatically. At 56 h, chl a content in parasitized $G$. instriatum culture again increased to $143.5 \pm 17.66 \mathrm{pg} \mathrm{chl} \mathrm{a} \mathrm{cell}{ }^{-1}$, probably due to the persistence of some uninfected or very recently infected hosts cells following the mortality of hosts in late stages of infection.

Phaeopigment content of infected Akashiwo sanguinea culture remained constant $\left(\sim 3 \mathrm{mg} \mathrm{m}^{-3}\right)$ until $16 \mathrm{~h}$ and then gradually increased to $10.3 \mathrm{mg} \mathrm{m}^{-3}$ by $64 \mathrm{~h}$, with corresponding decreases in cellular chl a contents (Fig. 1B). By comparison, phaeopigment concentration in parasitized Gymnodinium instriatum cultures was undetectable through $40 \mathrm{~h}$ and then abruptly increased to $2.6 \mathrm{mg} \mathrm{m}^{-3}$ by $48 \mathrm{~h}$ (Fig. 1D).

\section{Photosynthetic performance in infected and uninfected hosts}

Uninfected Akashiwo sanguinea and Gymnodinium instriatum showed strong diel periodicity in photosynthesis, with amplitude of the diel rhythms on a cellular basis $\left(\mathrm{P}^{\text {cell }}\right)$ averaging 1.7 (1.8 for $\left.\mathrm{P}^{\mathrm{chl}}\right)$ and 2.5 (2.8 for $\left.\mathrm{P}^{\mathrm{chl}}\right)$, respectively (Fig. 2). Maximum photosynthetic rate occurred in the morning for A. sanguinea and in the after- noon for $G$. instriatum, when based on the measurements made at $8 \mathrm{~h}$ intervals. Photosynthetic patterns of parasitized A. sanguinea and $G$. instriatum were distinctly different from those of uninfected cultures. Infected A. sanguinea showed no obvious diel rhythm in photosynthesis. Rather, phtosynthetic rate decreased during the first $16 \mathrm{~h}$ of infection and then remained constant throughout the rest of the infection cycle (Fig. 2A,B). By contrast, infected $G$. instriatum continued to show a periodicity until $40 \mathrm{~h}$ after infection, with the diel amplitude more or less dampened relative to controls, averaging 2.1 and 1.9 for $\mathrm{P}^{\text {cell }}$ and $\mathrm{P}^{\mathrm{chl}}$, respectively (Fig. 2C,D).

Photosynthetic performance of infected Akashiwo sanguinea, on a per cell and per chl a bases, was as high as $\sim 90 \%$ of that in uninfected controls at $8 \mathrm{~h}$ but decreased sharply after $16 \mathrm{~h}$ (Fig. 3). After 24 h, $\mathrm{P}^{\text {cell }}$ ratio (i.e., ratio of infected $\mathrm{P}^{\text {cell }}$ relative to uninfected $\mathrm{P}^{\text {cell }}$ ) varied between 0.15 and 0.47 , whereas $\mathrm{P}^{\text {chl }}$ ratio (i.e. ratio of infected $\mathrm{P}^{\mathrm{chl}}$ relative to uninfected $\mathrm{P}^{\mathrm{chl}}$ ) varied between 0.29 and 0.56. By comparison, infected Gymnodinium instriatum continued to maintain photosynthetic performance as high as $\sim 80 \%$ of that in uninfected cultures until $40 \mathrm{~h}$. After $48 \mathrm{~h}$, however, the photosynthetic performance of infected $G$. instriatum showed different patterns depending on the variables to which photosynthetic rates were normalized: $\mathrm{P}^{\text {cell }}$ ratio decreased sharply to 0.32 at $48 \mathrm{~h}$ and then increased to 0.56 at $56 \mathrm{~h}$ (Fig. $3 \mathrm{~A}$ ), whereas $\mathrm{P}^{\mathrm{chl}}$ ratio decreased to 0.60 at $48 \mathrm{~h}$ and then continued to decrease to 0.46 by $56 \mathrm{~h}$ (Fig. 3B).

\section{P-E parameters in infected and uninfected hosts}

Parasite prevalence averaged 98 and $96 \%$ for $A k a-$ shiwo sanguinea and Gymnodinium instriatum, respectively, during the P-E curve study. As in the preceding experiment, cell densities in parasitized cultures of both host species remained stable until the end of the infection cycle, while cell abundance steadily increased in uninfected controls (data not shown).

$\mathrm{P}_{\max }^{\text {chl }}$ and $\mathrm{P}_{\max }^{\text {cell }}$ for infected and uninfected cultures of Akashiwo sanguinea were comparable $1 \mathrm{~h}$ after inoculation; however, values for parasitized cultures were 


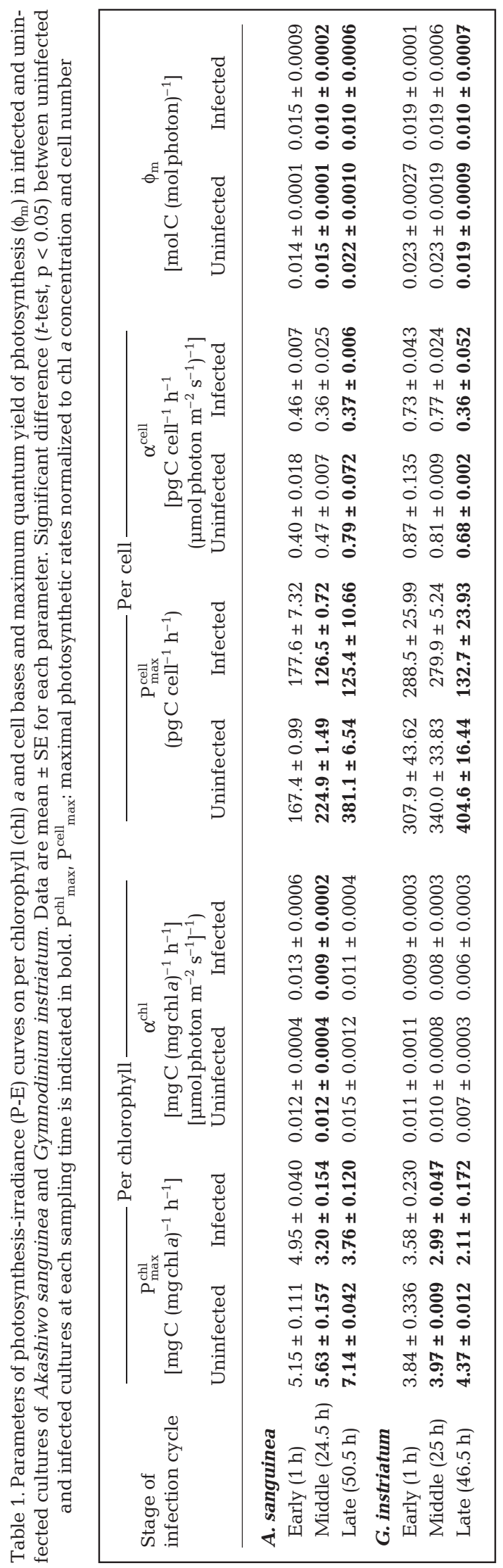
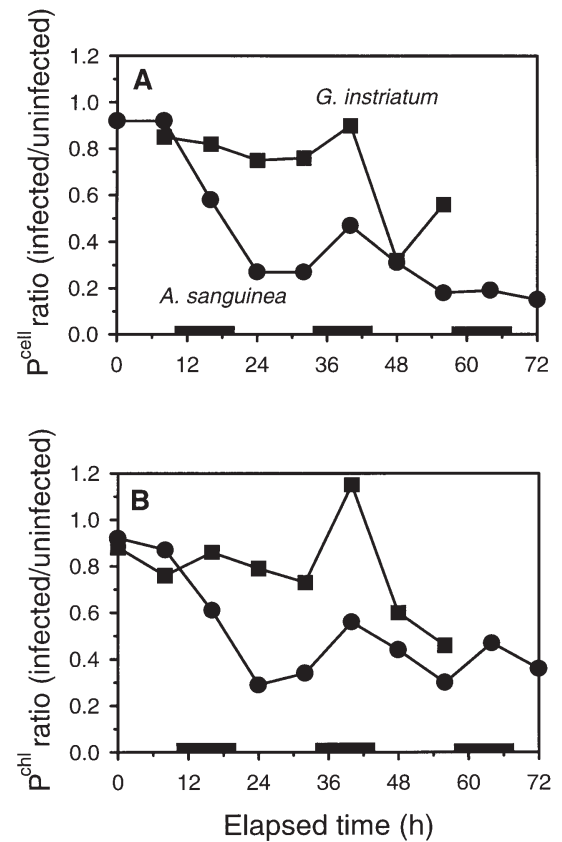

Fig. 3. Ratio of photosynthesis on (A) per cell and (B) per chl a bases between infected and uninfected cultures of Akashiwo

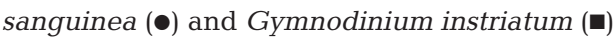

A. sanguinea
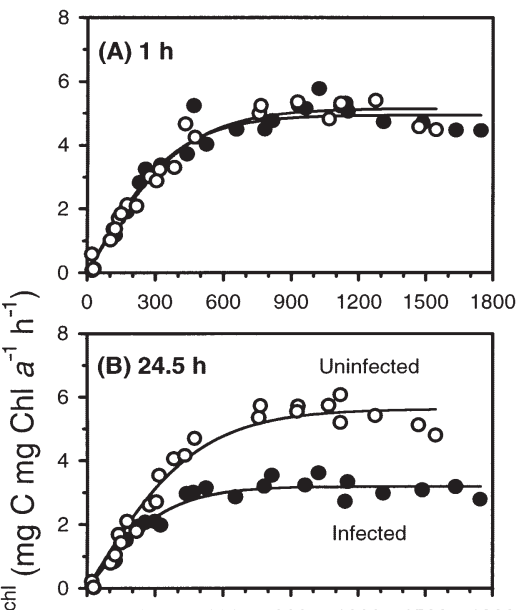

突

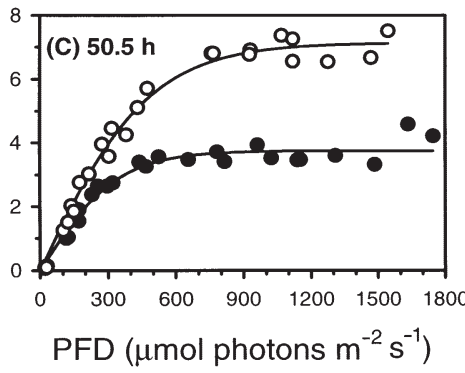

G. instriatum
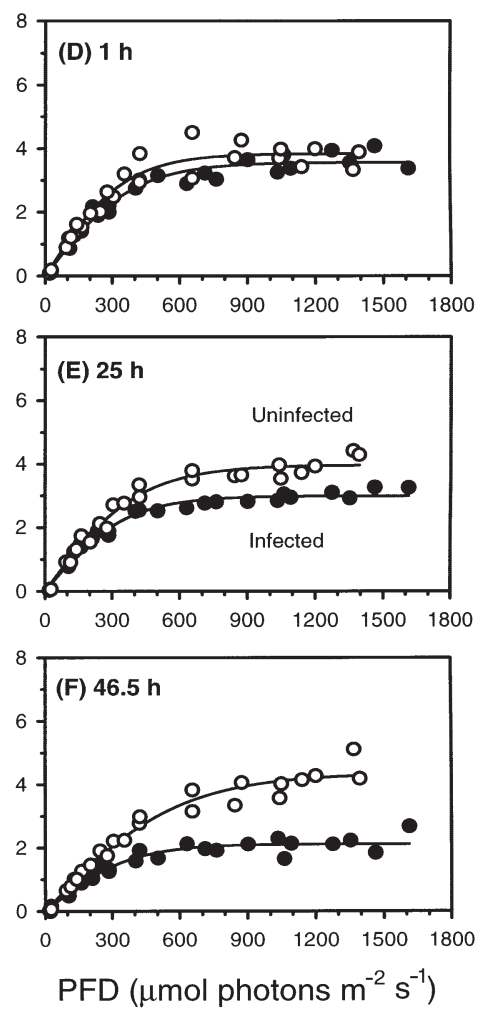

Fig. 4. Photosynthesis-irradiance ( $\left.\mathrm{P}^{\mathrm{chl}}-\mathrm{E}\right)$ curves on a per chl a basis in infected (•) and uninfected (O) cultures of (A to C) Akashiwo sanguinea and (D to F) Gymnodinium instriatum. $\mathrm{P}^{\text {chl }}$-E curves were fitted with hyperbolic tangent equation. $\mathrm{n}=2$. PFD: photon flux density 
A. sanguinea
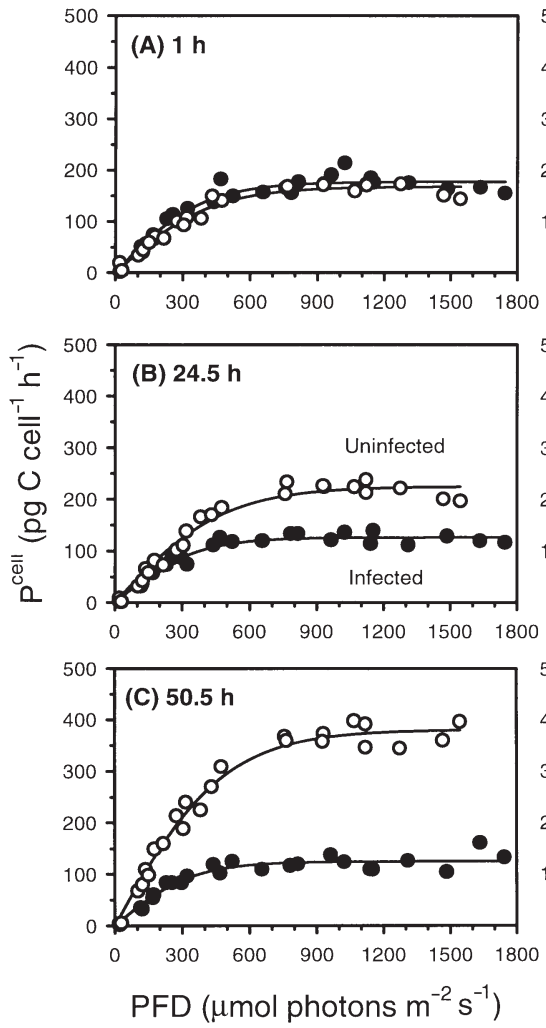

G. instriatum
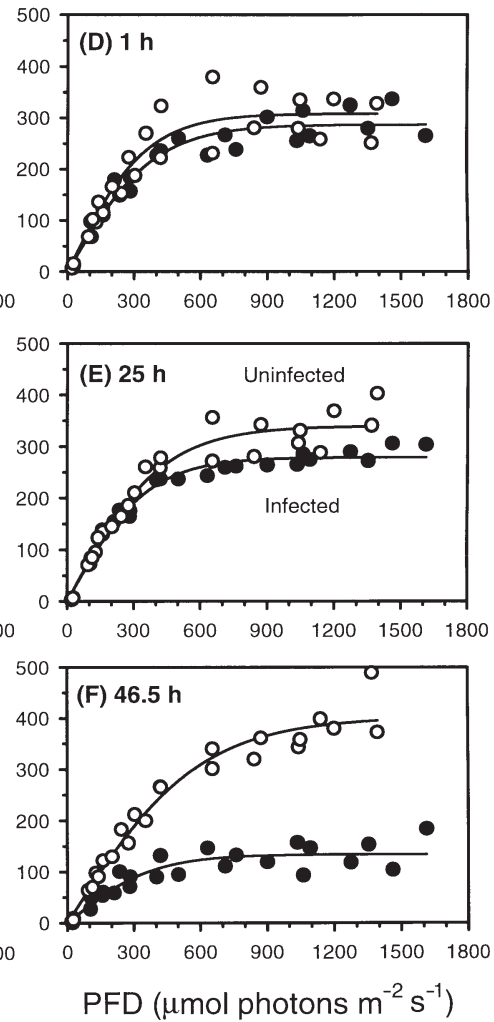

Fig. 5. Photosynthesis-irradiance ( $\mathrm{P}^{\text {cell }}$-E) curves on a per cell basis in infected (•) and uninfected (O) cultures of (A to C) Akashiwo sanguinea and (D to F) Gymnodinium instriatum. $\mathrm{P}^{\text {chl }}-\mathrm{E}$ curves were fitted with hyperbolic tangent equation. $\mathrm{n}=2$

significantly lower $(t$-test, $\mathrm{p}<0.05)$ than those of uninfected controls at subsequent sampling times (Table 1). Similarly, $\mathrm{P}_{\max }^{\text {chl }}$ and $\mathrm{P}_{\max }^{\text {cell }}$ for infected and uninfected cultures of Gymnodinium instriatum were comparable $1 \mathrm{~h}$ after inoculation, but diverged thereafter, with infected cultures having a significantly lower ( $t$-test, $\mathrm{p}<0.05$ ) $\mathrm{P}_{\text {max }}^{\text {chl }}$ than controls by $25 \mathrm{~h}$ and a significantly lower $\mathrm{P}_{\max }^{\text {cell by }} 46.5$ (Table 1). $\mathrm{P}_{\max }^{\text {chl }}$ and $\mathrm{P}_{\max }^{\text {cell }}$ of uninfected $A$. sanguinea and $G$. instriatum increased with successive samplings, perhaps reflecting diel oscillations in photosynthetic parameters. By contrast, values for infected $A$. sanguinea decreased after $1 \mathrm{~h}$ and then remained constant at $\sim 3.5 \mathrm{mg} \mathrm{C}(\mathrm{mg} \mathrm{chl} \mathrm{a})^{-1} \mathrm{~h}^{-1}$ and $\sim 126 \mathrm{pg} \mathrm{C}$ cell $^{-1} \mathrm{~h}^{-1}$ (Figs 4A,B,C \& 5A,B,C). Unlike that of infected A. sanguinea, $\mathrm{P}_{\max }^{\mathrm{chl}}$ and $\mathrm{P}_{\max }^{\text {cell }}$ of infected $G$. instriatum gradually decreased during the experiment (Figs 4D,E,F \& 5D,E,F).

Chl a-specific photosynthetic efficiency $\left(\alpha^{\mathrm{chl}}\right)$ was similar for infected and uninfected cultures of both species, with a significant difference $(t$-test, $\mathrm{p}<0.05)$ detected only between treatment and control cultures of Akashiwo sanguinea at $24.5 \mathrm{~h}$ (Table 1 \& Fig. 4). However, significant decreases (46 to $53 \%$ ) in $\alpha^{\text {cell }}$ of infected relative to uninfected controls were observed for A. sanguinea and Gymnodinium instriatum at 50.5 and $46.5 \mathrm{~h}$, respectively (Table 1 \& Fig. 5).

\section{Light absorption spectra and coefficients}

To examine difference in spectral absorption between uninfected and infected hosts, spectra for Akashiwo sanguinea were normalized to $600 \mathrm{~nm}$ and those for Gymnodinium instriatum normalized to $550 \mathrm{~nm}$ (Fig. 6), as parasitism had almost no affect at those wavelengths. Relative to uninfected controls, parasitized A. sanguinea showed no difference $1 \mathrm{~h}$ after inoculation but enhanced absorption in the blue region after $24.5 \mathrm{~h}$, with no difference in the red region $(676 \mathrm{~nm})$ of the spectrum (Fig. 6B). At 50.5 h, infected A. sanguinea had even greater absorption in the blue region but reduced absorption in the red region compared with uninfected cells (Fig. 6C). By contrast, no difference in the shape of $a^{* \operatorname{chl}}(\lambda)$ was observed between uninfected and infected G. instriatum $1 \mathrm{~h}$ and $25 \mathrm{~h}$ after infection (Fig. 6D,E), but reduced absorption in the red region $(676 \mathrm{~nm})$, without change in the blue region was evident in parasitized hosts at $46 \mathrm{~h}$ (Fig. 6F).

Mean $a^{* \text { chl }}$ for uninfected Akashiwo sanguinea and Gymnodinium instriatum ranged from 0.016 to $0.020 \mathrm{~m}^{2}(\mathrm{mg} \mathrm{chl} \mathrm{a})^{-1}$ and from 0.009 to $0.011 \mathrm{~m}^{2}$ $(\mathrm{mgchla})^{-1}$, respectively (Fig. $\left.7 \mathrm{~B}, \mathrm{D}\right)$. Values for $a^{* \text { chl }}$ in parasitized $A$. sanguinea at 24.5 and $50.5 \mathrm{~h}$ were significantly greater $(t$-test, $\mathrm{p}<0.001)$ than those in uninfected cells. In $G$. instriatum, a significant difference $(t$-test, $\mathrm{p}<0.001)$ in $a^{* \text { chl }}$ between uninfected and infected hosts was found only at $46.5 \mathrm{~h}$ (Fig. 7D). The only significant differences between $a^{* \text { cell }}$ values for uninfected and infected cells of either species was evident for $A$. sanguinea at $24.5 \mathrm{~h}$ (Fig. 7A,C).

\section{Maximum quantum yield}

Estimates for quantum yield of photosynthesis $\left(\phi_{\mathrm{m}}\right)$ were comparable when expressed on per chl $a$ and per cell bases. Values for $\phi_{\mathrm{m}}$ in uninfected hosts ranged from 0.014 to $0.022 \mathrm{~mol} \mathrm{C}$ (mol photons) $)^{-1}$ for Akashiwo sanguinea and from 0.019 to $0.023 \mathrm{~mol} \mathrm{C} \mathrm{(mol} \mathrm{pho-}$ tons) $)^{-1}$ for Gymnodinium instriatum (Table 1). The quantum yield of infected $A$. sanguinea was significantly different $(t$-test, $\mathrm{p}<0.05)$ from that of uninfected A. sanguinea at 24.5 and $50.5 \mathrm{~h}$, with the means $\phi_{\mathrm{m}}$ of uninfected host being 1.5- and 2.2-fold greater than those of infected host. A significant difference ( $t$-test, 
A. sanguinea

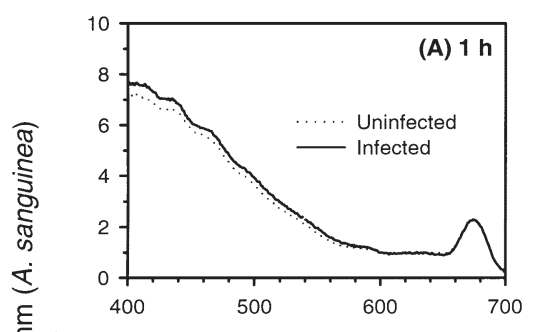

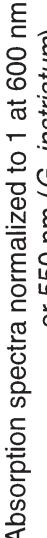

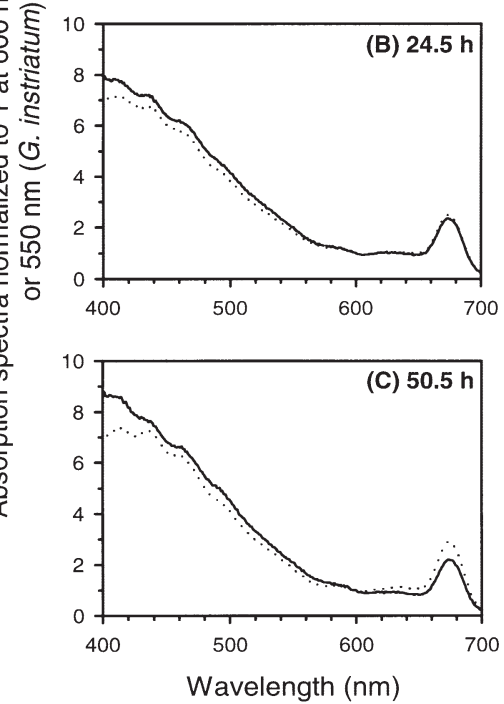

Fig. 6. Average absorption spectra for infected (-) and uninfected $(\cdots)$ cultures of (A to C) Akashiwo sanguinea and (D to F) Gymnodinium instriatum normalized to 1 at $600 \mathrm{~nm}(A$. sanguinea) and $550 \mathrm{~nm}$ (G. instriatum). $\mathrm{n}=2$
A. sanguinea
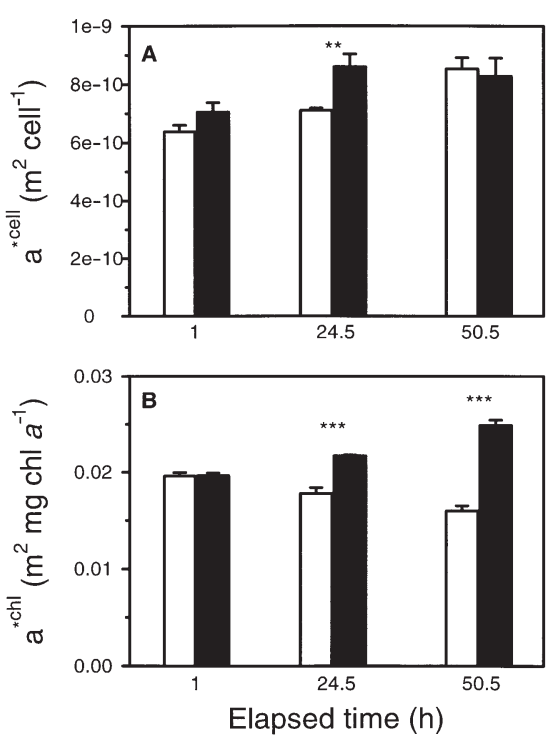

G. instriatum
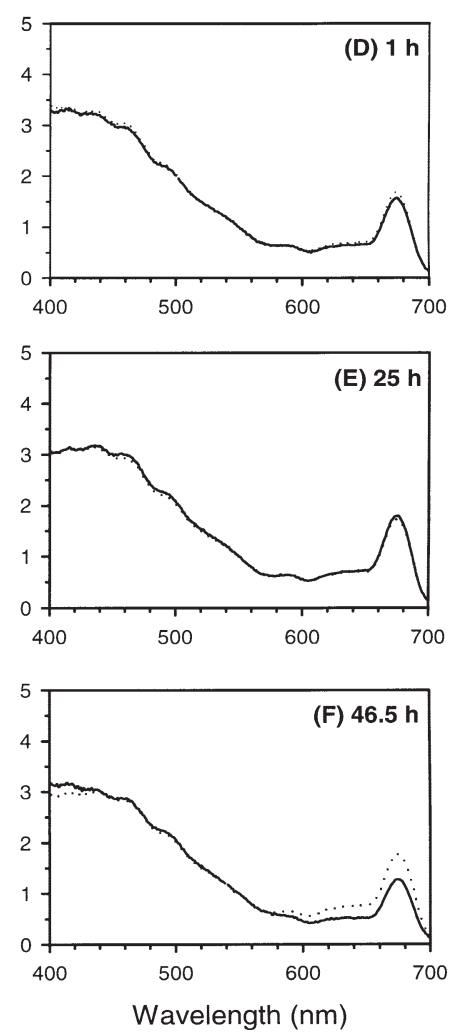

$\mathrm{p}<0.05$ ) in quantum yield of $G$. instriatum was only observed between uninfected and infected cultures at $46.5 \mathrm{~h}$, with uninfected controls being 2.0-fold higher than parasitized cultures.

\section{DISCUSSION}

Our data clearly show that photosynthetic performance and photophysiological properties of the bloom-forming dinoflagellates Akashiwo sanguinea and Gymnodinium instriatum are significantly altered following infection by parasitic dinoflagellates of the genus Amoebophrya. Furthermore, the magnitude of these effects and the manner in which they are manifested differ between the 2 host species. Possible causes for observed differences and their ecological and photophysiological implications are discussed below.

\section{Parasitic impact on photosynthesis and its ecological implication}

Uninfected Akashiwo sanguinea and Gymnodinium instriatum showed strong diel periodicity in photosynthesis similar to that reported for other dinoflagellates (Prézelin et al. 1977, Prézelin \& Sweeney 1977, Samuelsson et al. 1983; for review, see Prézelin 1992); however, infected hosts exhibited distinctly different patterns. Specifically, parasitized A. sanguinea lost diel periodicity shortly after infection, whereas infected $G$. instriatum continued to show a diel rhythm that was less pronounced than that of uninfected cells. Observed differences in photosynthetic periodicity of infected $A$. sanguinea and G. instriatum suggest that the 2 host-parasite systems behave in very different ways. Interestingly, Amoebophrya sp. ex A. sanguinea always invades the host's nucleus (Coats \& Bockstahler 1994), while Amoebophrya sp. ex G. instriatum grows within the host's cytoplasm. The difference in photosynthetic periodicity between the 2 host species may be due to the different sites of parasite infection. For example, intranuclear growth of the parasite might knock out RNA-protein systems like 'Per', a nuclear protein required for circadian rhythmicity (Takahashi 1992). Furthermore, intranuclear growth of the parasite might inhibit production of certain proteins essential for
Fig. 7. (A,C) Cell-specific and $(B, D)$ chl a-specific absorption coefficients for infected (dark bars) and uninfected (white bars) cultures of $(\mathrm{A}, \mathrm{B})$ Akashiwo sanguinea and $(\mathrm{C}, \mathrm{D})$ Gymnodinium instriatum. Error bars indicate SE of mean $(\mathrm{n}=2) .{ }^{* *} \mathrm{p}<0.01,{ }^{* * *} \mathrm{p}<0.001$ 
photosynthesis (e.g. light-harvesting chlorophyll proteins and components of Cytochrome $b_{6} / f$ complex encoded in the nucleus; Falkowski \& Raven 1997). An abrupt deficiency in such proteins might explain the sharp drop in photosynthetic performance observed shortly after infection in A. sanguinea. By comparison, intracytoplasmic infection of $G$. instriatum caused a steady reduction in photosynthetic capacity that may reflect a gradual decrease in number or turnover rate of photosynthetic units (Prézelin 1981, 1987, Falkowski \& Raven 1997), reduced ribulose 1,5-bisphosphate carboxylase/oxygenase (Rubisco) concentration per cell (Orellano \& Perry 1992) or a lower Rubisco/Electron Transport Chain (ETC) ratio (Sukenik et al. 1987).

Infected Gymnodinium instriatum continued to maintain high photosynthetic performance $(\sim 80 \%$ of uninfected cell) and had a cellular chl a content equivalent to that of uninfected cells until very late in the infection cycle, suggesting that the photosynthetic apparatus of this host species continued to function normally for a considerable time following infection. In spite of this, infected G. instriatum failed to reproduce. There are at least 3 possible explanations for this apparent discrepancy: (1) photosynthetic products might be shunted to recovery of the cell structures (e.g., photosynthetic apparatus) damaged by the endoparasite; (2) the parasite may rely heavily on host photosynthate for growth; and (3) infected G. instriatum cells may become 'leaky' and lose much of their photosynthate as dissolved organic matter. Resolution of the possibilities will require additional study. However, it is interesting that phaeopigments increased over the infection cycle of Akashiwo sanguinea, suggesting extensive chlorophyll degradation. By contrast, phaeopigments did not accumulate in G. instriatum, suggesting that (1) parasitism does not damage chloroplasts of $G$. instriatum; (2) G. instriatum recycles phaeopigments to repair parasite-induced damage of the photosynthetic machinery; or (3) the parasite completely digests chloroplasts of $G$. instriatum, with new structures being synthesized de novo.

The prevalence of Amoebophrya spp. in phytoplankton communities is highly variable, ranging from $<1$ to $80 \%$ for particular host species (Taylor 1968, Elbrächter 1973, Nishitani \& Chew 1984, Nishitani et al. 1984, 1985, Fritz \& Nass 1992, Coats \& Bockstahler 1994, Coats et al. 1996; for recent review see Coats 1999), with the epidemic outbreaks usually associated with periodic or seasonal maxima in host abundance (Coats et al. 1996). Thus, parasite-induced mortality of host populations fluctuates considerably in time and space. Our results indicate that parasitism may also have varying impacts on primary production, and perhaps trophodynamics, of plankton assemblages, de- pending on the nature of the particular host-parasite system. Epidemic outbreaks of endonuclear species of Amoebophrya in blooms of Akashiwo sanguinea, or similar host species, should significantly reduce primary productivity before host mortality. By contrast, epidemics of intracytoplasmic an Amoebophrya sp. in blooms of Gymnodinium instriatum, or similar hosts, should have much less effect on primary production before host mortality, but might increase the release of dissolved organic compounds from algal cells and in turn enhance bacterial production and microbial food web processes.

\section{Parasitism and its photophysiological implications}

Chl $a$-specific absorption coefficient $\left(a^{* \text { chl }}\right)$ and quantum yield of photosynthesis $\left(\phi_{\mathrm{m}}\right)$ are key photophysiological parameters in many bio-optical models that provide estimates of phytoplankton biomass and productivity over a variety of temporal and spatial scales (Bidigare et al. 1992). Further, light absorption spectra furnish information about major pigment groups of phytoplankton (Hoepffner \& Sathyendranath 1993) and are useful in distinguishing phytoplankton taxa (Johnsen et al. 1994). Spectral absorption data have even been used to detect and quantify HAB species in mixed phytoplankton populations (Millie et al. 1997, Lohrenz et al. 1999). For example, Millie et al. (1997) recently applied this approach to determine the relative abundance of the toxic dinoflagelate Gymnodinium breve in cultures of mixed algae.

The magnitude and the spectral shape of $a^{* \operatorname{chl}}(\lambda)$ are known to vary greatly in response to differences in species composition, cell size, light history, and nutrient conditions in the field, and can even vary within species due to pigmentation and package effects associated with photoacclimation and physiological status (Sathyendranath et al. 1987, Mitchell \& Kiefer 1988, Sosik \& Mitchell 1991, 1994, Kirk 1994, Bricaud et al. 1995, Culver \& Perry 1999, Stuart et al. 2000). In addition, our results suggest that endoparasites may contribute significantly to variations in the magnitude and the shape of $a^{* \text { chl }}(\lambda)$ within species, particularly in midto late stages of infection. Growth of Amoebophrya spp. within host cells caused light absorption to increase in the blue region and decrease in the red region of the spectrum Thus, deriving dinoflagellate biomass, in terms of cell density rather than chl a concentration, using the absorption spectrum alone (in particular, the red region) would significantly underestimate population size during epidemic infections. Values for $a^{* \text { chl }}$ of infected hosts increased relative to uninfected cells by as much as 22 to $56 \%$ in Akashiwo sanguinea and $59 \%$ in Gymnodinium instriatum. Inter- 
estingly, enhanced light absorption in the blue region following infection only occurred in A. sanguinea and was apparently associated with increased phaeopigment concentration. Thus, the parasite and associated phaeopigments are nonphotosynthetic particles (Cleveland et al. 1989) that contribute significantly to enhanced absorption at blue wavelengths and thereby lower $\phi_{\mathrm{m}}$ even in the middle of the infection cycle.

Laboratory and field studies have shown that $\phi_{\mathrm{m}}$ can vary in response to a variety of environmental and biological variables, including nutrient limitation and stress (Welschmeyer \& Lorenzen 1981, Cleveland \& Perry 1987, Kolber et al. 1988, Cleveland et al. 1989, Sosik \& Mitchell 1991), light quantity and quality (Bidigare et al. 1989, Schofield et al. 1996), photoprotective pigments (Bidigare et al. 1989, Prézelin et al. 1990, 1991, Babin et al. 1996, Stuart et al. 2000), temperature (Tilzer et al. 1985, Sosik \& Mitchell 1994), and diurnal periodicity in algal biology (Prézelin 1992). Our results indicate that parasitism may also contribute to natural variations in quantum yield, as infection by Amoebophrya spp. lowered $\phi_{\mathrm{m}}$ of Akashiwo sanguinea and Gymnodinium instriatum by a factor of ca 2 . Reduced $\phi_{\mathrm{m}}$ following infection of these 2 dinoflagellates resulted from parasite-induced enhancement of $a^{* \text { chl }}$ rather than changes in $\alpha^{\mathrm{chl}}$, except in late stage infections when both factors (i.e., higher $a^{* \text { chl }}$ and lower $\alpha^{\text {chl }}$ ) became important. Thus, endoparasites like Amoebophrya spp. apparently act like nonphotosynthetic or photoprotective pigments that absorb light but do not transfer excitation energy to photosynhetic reaction centers.

Acknowledgements. This research was supported by NSF Grant No. OCE-9730695 awarded to D.W.C. and by a travel allowance from the 2000 KNU RRC (Kunsan National Universtiy Regional Research Center) program to W.Y. We thank Patrick Neale, who kindly provided access to the photosynthetron and spectrophotometer. We also thank Patrick Neale, Jason Adolf, Graham Savidge, and 3 anonymous reviewers for their helpful comments on the manuscript.

\section{LITERATURE CITED}

Anderson DM (1997) Turning back the harmful red tide. Nature 388:513-514

Babin M, Morel A, Claustre H, Bricaud A, Kolber Z, Falkowski PG (1996) Nitrogen- and irradiance-dependent variations of the maximum quantum yield of carbon fixation in eutrophic, mesotrophic and oligotrophic marine systems. Deep-Sea Res 43:1241-1272

Bidigare RR, Schofield O, Prézelin BB (1989) Influence of zeaxanthin on quantum yield of photosynthesis of Synechococcus clone WH7803 (DC2). Mar Ecol Prog Ser 56: 177-188

Bidigare RR, Prézelin BB, Smith RC (1992) Bio-optical models and the problems of scaling. In: Falkowski PG, Woodhead $\mathrm{AD}$ (eds) Primary productivity and biogeochemical cycles in the sea. Plenum Press, New York, p 175-212
Bratbak G, Egge JK, Heldal M (1993) Viral mortality of the marine alga Emiliania huxleyi (Haptophyceae) and termination of algal blooms. Mar Ecol Prog Ser 93:39-48

Bratbak G, Levasseur M, Michaud S, Cantin G, Fernández E, Heimdal BR, Heldal M (1995) Virus activity in relation to Emiliania huxleyi blooms: a possible mechanism of DMSP release? Mar Ecol Prog Ser 128:133-142

Bricaud A, Stramski D (1990) Spectral absorption coefficients of living phytoplankton and nonalgal biogenous matter: a comparison between the Peru upwelling area and the Sargasso Sea. Limnol Oceanogr 35:562-582

Bricaud A, Babin M, Morel A, Claustre H (1995) Variability in the chlorophyll-specific absorption coefficients of natural phytoplankton: analysis and parameterization. J Geophys Res 100:13321-13332

Bruning K, Lingeman R, Ringelberg J (1992) Estimating the impact of fungal parasites on phytoplankton populations. Limnol Oceanogr 37:252-260

Brussaard CPD, Thyrhaug R, Marie D, Bratbak G (1999) Flow cytometric analyses of viral infection in two marine phytoplankton species, Micromonas pusilla (Prasinophyceae) and Phaeocystis pouchetii (Prymnesiophyceae). J Phycol 35:941-948

Cachon J (1964) Contribution a l'etude des peridiniens parasites cytologie, cycles evolutifs. Ann Sci Nat Zool 6:1-158

Cachon J, Cachon M (1987) Parasitic dinoflagellates. In: Taylor FJR (ed) The biology of dinoflagellates. Blackwell Science, Oxford, p 571-610

Cleveland JS, Perry MJ (1987) Quantum yield, relative specific absorption and fluorescence in nitrogen-limited Chaetoceros gracilis. Mar Biol 94:489-497

Cleveland JS, Perry MJ, Kiefer DA, Talbot MC (1989) Maximal quantum yield of photosynthesis in the northwestern Sargasso Sea. J Mar Res 47:869-886

Coats DW (1999) Parasitic life styles of marine dinoflagellates. J Eukaryot Microbiol 46:402-409

Coats DW, Bockstahler KR (1994) Occurrence of the parasitic dinoflagellate Amoebophrya cetatii in Chesapeake Bay populations of Gymnodinium sanguineum. J Eukaryot Microbiol 41:586-593

Coats DW, Heinbokel JF (1982) A study of reproduction and other life cycle phenomena in planktonic protists using an acridine orange fluorescence technique. Mar Biol 67:71-79

Coats DW, Adam EJ, Gallegos CL, Hedrick S (1996) Parasitism of photosynthetic dinoflagellates in a shallow subestuary of Chesapeake Bay, USA. Aquat Microb Ecol 11:1-9

Culver ME, Perry MJ (1999) The response of photosynthetic absorption coefficients to irradiance in culture and in tidally mixed estuarine waters. Limnol Oceanogr 44:24-36

Doucette GJ (1995) Interaction between bacteria and harmful algae: a review. Nat Toxins 3:65-74

Doucette GJ, McGovern ER, Babinchak JA (1999) Algicidal bacteria active against Gymnodinium breve (Dinophyceae). I. Bacterial isolation and characterization of killing activity. J Phycol 35:1447-1454

Elbrächter M (1973) Population dynamics of Ceratium in coastal waters of Kiel Bay. Oikos 15(Suppl):43-48

Erard-Le Denn E, Chrétiennot-Dinet MJ, Probert I (2000) First report of parasitism on the toxic dinoflagellate Alexandrium minutum Halim. Estuar Coast Shelf Sci 50: 109-113

Falkowski PG, Raven JA (1997) Aquatic photosynthesis. Blackwell Science, Malden

Fritz L, Nass M (1992) Development of the parasitic dinoflagellate Amoebophrya cetatii within host dinoflagellate species. J Phycol 28:312-320

Fukami K, Nishijima T, Murata H, Doi S, Hata Y (1991) Distri- 
bution of bacteria influential on the development and the decay of Gymnodinium nagasakiense red tide and their effects on algal growth. Nippon Suisan Gakkaishi 57: 2321-2326

Fukami K, Yuzawa A, Nishijima T, Hata Y (1992) Isolation and properties of a bacterium inhibiting the growth of Gymnodinium nagasakiense. Nippon Suisan Gakkaishi 58: 1073-1077

Gobler CJ, Hutchins DA, Fisher NS, Cosper EM, SanudoWilhelmy SA (1997) Release and bioavailability of C, N, P, $\mathrm{Se}$, and $\mathrm{Fe}$ following viral lysis of a marine chrysophyte. Limnol Oceanogr 42:1492-1504

Guillard RRL, Ryther JH (1962) Studies on marine planktonic diatoms. I. Cyclotella nana Hustedt and Detonula confervacea (Cleve) Gran. Can J Microbiol 8:229-239

Gunderson JH, Goss SH, Coats DW (1999) The phylogenetic position of Amoebophrya sp. from Gymnodinium sanguineum. J Eukaryot Microbiol 46:194-197

Hallegraeff GM (1993) A review of harmful algal blooms and their apparent global increase. Phycologia 32:79-99

Hill RW, White BA, Cottrell MT, Dacey JWH (1998) Virusmediated total release of dimethylsulfoniopropionate from marine phytoplankton: a potential climate process. Aquat Microb Ecol 14:1-6

Hoepffner N, Sathyendranath S (1993) Determination of the major groups of phytoplankton pigments from the absorption spectra of total particulate matter. J Geophys Res 98: 22789-22803

Imai I, Ishida Y, Hata Y (1993) Killing of marine phytoplankton by gliding bacterium Cytophaga sp., isolated from the coastal sea of Japan. Mar Biol 116:527-532

Jassby AD, Platt T (1976) Mathematical formulation of the relationship between photosynthesis and light for phytoplankton. Limnol Oceanogr 21:540-547

Jeong HJ, Shim JH, Lee CW, Kim JS, Koh SM (1999a) Growth and grazing rates of the marine planktonic ciliate Strombidinopsis sp. on red-tide and toxic dinoflagellates. J Eukaryot Microbiol 46:69-76

Jeong HJ, Shim JH, Kim JS, Park JY, Lee CW, Lee Y (1999b) Feeding by the mixotrophic thecate dinoflagellate Fragilidium cf. Mexicanum on red-tide and toxic dinoflagellates. Mar Ecol Prog Ser 176:263-277

Johnsen G, Samset O, Granskog L, Sakshaug E (1994) In vivo absorption characteristics in 10 classes of bloom-forming phytoplankton: taxonomic characteristic and responses to photoadaptation by means of discriminant and HPLC analysis. Mar Ecol Prog Ser 105:149-157

Kamiyama T (1997) Growth and grazing responses of tintinnid ciliates feeding on the toxic dinoflagellate Heterocapsa circularisquama. Mar Biol 128:509-515

Kirk JTO (1994) Light and photosynthesis in aquatic ecosystems. Cambridge University Press, Cambridge

Kolber Z, Zehr J, Falkowski PG (1988) Effects of growth irradiance and nitrogen limitation on photosynthetic energy conversion in photosystem II. Plant Physiol 88:923-929

Lewis MR, Smith JC (1983) A small volume, short-incubation-time method for measurement of photosynthesis as a function of incident irradiance. Mar Ecol Prog Ser 13: 99-102

Lohrenz SE, Fahnenstiel GL, Kirkpatrick GJ, Carroll CL, Kelly KA (1999) Microphotometric assessment of spectral absorption and its potential application for characterization of harmful algal species. J Phycol 35:1438-1446

Lovejoy C, Bowman JP, Hallegraeff GM (1998) Algacidal effects of a novel marine Pseudoalteromonas isolate (Class Proteobacteria, Gamma Subdivision) on harmful algal bloom species of the genera Chattonella, Gymno- dinium, and Heterosigma. Appl Environ Microbiol 64: $2806-2813$

Matsuyama Y, Miyamoto M, Kotani Y (1999) Grazing impacts of the heterotrophic dinoflagellate Polykrikos kofoidii on a bloom of Gymnodinium catenatum. Aquat Microb Ecol 17: 91-98

Millie DF, Schofield OM, Kirkpatrick GJ, Johnsen G, Tester PA, Vinyard BT (1997) Detection of harmful algal blooms using photopigments and absorption signatures: a case study of the Florida red-tide dinoflagellate, Gymnodinium breve. Limnol Oceanogr 42:1240-1251

Milligan KLD, Cosper EM (1994) Isolation of virus capable of lysing the brown tide microalga, Aureococcus anophagefferens. Science 266:805-807

Mitchell BG, Kiefer DA (1988) Chlorophyll a specific absorption and fluorescence excitation spectra for lightlimited phytoplankton. Deep-Sea Res 35:639-663

Nagasaki K, Yamaguchi M (1997) Isolation of a virus infectious to the harmful bloom causing microalga Heterosigma akashiwo (Raphidophyceae). Aquat Microb Ecol 13: 135-140

Nagasaki K, Ando M, Imai I, Ishida Y (1994a) Viral mortality in the final stage of Heterosigma akashiwo (Raphidophyceae) red tide. J Plankton Res 16:1595-1599

Nagasaki K, Ando M, Itakura S, Imai I, Ishida Y (1994b) Viruslike particles in Heterosigma akashiwo (Raphidophyceae): a possible red tide disintegration mechanism. Mar Biol 119: 307-312

Nagasaki K, Tarutani K, Yamaguchi M (1999) Growth characteristics of Heterosigma akashiwo virus and its possible use as a microbiological agent for red tide control. Appl Environ Microbiol 65:898-902

Nakamura Y, Suzuki S, Hiromi J (1995) Population dynamics of heterotrophic dinoflagellates during a Gymnodinium mikimotoi red tide in the Seto Inland Sea. Mar Ecol Prog Ser 125:269-277

Nishitani L, Chew KK (1984) Recent developments in paralytic shellfish poisoning research. Aquaculture 39:317-329

Nishitani L, Hood R, Wakeman J, Chew KK (1984) Potential importance of an endoparasite of Gonyaulax in paralytic shellfish poisoning outbreaks. In: Ragelis EP (ed) Seafood toxins. ACS Symp Ser 262:139-149

Nishitani L, Erickson G, Chew KK (1985) Role of the parasitic dinoflagellate Amoebophrya ceratii in control of Gonyaulax catenella populations. In: Anderson DM, White AW, Baden DG (eds) Toxic dinoflagellates. Elsevier Science Publishers, New York, p 225-230

Norén F, Moestrup Ø, Rehnstam-Holm AS (1999) Parvilucifera infectans Norén et Moestrup gen. et sp. nov. (Perkinsozoa phylum nov.): a parasitic flagellate capable of killing toxic microalgae. Eur J Protistol 35:233-254

Orellano MV, Perry MJ (1992) An immunoprobe to measure Rubisco concentrations and maximal photosynthetic rates of individual phytoplankton cells. Limnol Oceanogr 37: 478-490

Parsons TR, Maita Y, Lalli CM (1984) A manual of chemical and biological methods for seawater analysis. Pergamon Press, Oxford

Prézelin BB (1981) Light reactions in photosynthesis. In: Platt T (ed) Physiological bases of phytoplankton ecology. Can Bull Fish Aquat Sci 210:1-43

Prézelin BB (1987) Photosynthetic physiology of dinoflagellates. In: Taylor FJR (ed) The biology of dinoflagellates. Blackwell Science, Oxford, p 174-223

Prézelin BB (1992) Diel periodicity in phytoplankton productivity. Hydrobiologia 238:1-35

Prézelin BB, Sweeney BM (1977) Characterization of photo- 
synthetic rhythms in marine dinoflagellates. II. Photosynthesis-irradiance curves and in vivo chlorophyll a fluorescence. Plant Physiol 60:388-392

Prézelin BB, Meeson BW, Sweeney BM (1977) Characterization of photosynthetic rhythms in marine dinoflagellates. I. Pigmentation, photosynthetic capacity and respiration. Plant Physiol 60:384-387

Prézelin BB, Smith RC, Bidigare RR (1990) Photosynthetic quantum yield and light utilization efficiency in the Southern California Bight. EOS 71:146

Prézelin BB, Tilzer MM, Schofield O, Haese C (1991) The control of the production process of phytoplankton by the physical structure of the aquatic environment with special reference to its optical properities. Aquat Sci 53:136-186

Samuelsson G, Sweeney BM, Matlick HA, Prézelin BB (1983) Changes in photosystem II account for the circadian rhythm in photosynthesis in Gonyaulax polyedra. Plant Physiol 73:329-331

Sathyendranath S, Lazzara L, Prieur L (1987) Variations in the spectral values of specific absorption of phytoplankton. Limnol Oceanogr 32:403-415

Schofield O, Prézelin BB, Johnsen G (1996) Wavelength dependency of the maximum quantum yield of carbon fixation for two red tide dinoflagellates, Heterocapsa pygmaea and Prorocentrum minimum (Pyrrophyta): implications for measuring photosynthetic rates. J Phycol 32:574-583

Sosik HM, Mitchell BG (1991) Absorption, fluorescence and quantum yield for growth in nitrogen limited Dunaliella tertiolecta. Limnol Oceanogr 36:910-921

Sosik HM, Mitchell BG (1994) The effects of temperature on growth, light absorption, and quantum yield in Dunaliella tertiolecta (Chlorophyceae). J Phycol 30:833-840

Stuart V, Sathyendranath S, Head EJH, Platt T, Irwin B, Maass $\mathrm{H}$ (2000) Bio-optical characteristics of diatom and prymnesiophyte populations in the Labrador Sea. Mar Ecol Prog Ser 201:91-106

Sukenik A, Bennett J, Falkowski PG (1987) Light-saturated

Editorial responsibility: Otto Kinne (Editor), Oldendorf/Luhe, Germany photosynthesis-limitation by electron transport or carbon fixation? Biochim Biophys Acta 891:205-215

Suttle CA (1992) Inhibition of photosynthesis in phytoplankton by the submicron size fraction concentrated from seawater. Mar Ecol Prog Ser 87:105-112

Suttle CA, Chan AM (1993) Marine cyanophages infecting oceanic and coastal strains of Synechococcus: abundance, morphology, cross-infectivity and growth characteristics. Mar Ecol Prog Ser 92:99-109

Suttle CA, Chan AM, Cottrell MT (1990) Infection of phytoplankton by viruses and reduction of primary productivity. Nature 347:467-469

Takahashi JS (1992) Circadian clock genes are ticking. Science 258:238-240

Tarutani K, Nagasaki K, Yamaguchi M (2000) Viral impacts on total abundance and clonal composition of the harmful bloom-forming phytoplankton Heterosigma akashiwo. Appl Environ Microbiol 66:4916-4920

Tassan S, Ferrari GM (1995) An alternative approach to absorption measurements of aquatic particles retained on filters. Limnol Oceanogr 40:1358-1368

Taylor FJR (1968) Parasitism of the toxin-producing dinoflagellate Gonyaulax catenella by the endoparasitic dinoflagellate Amoebophrya ceratii. J Fish Res Board Can 25: 2241-2245

Tilzer MM, Bodungen B, Smetacek V (1985) Light-dependence of phytoplankton photosynthesis in the Antarctic ocean: implications for regulating productivity. In: Siegfried WR, Condy PR, Laws RM (eds) Antarctic nutrient cycles and food webs. Springer-Verlag, Berlin, p 60-69

Welschmeyer NA, Lorenzen CJ (1981) Chlorophyll-specific photosynthesis and quantum efficiency at subsaturating light intensities. J Phycol 17:283-293

Yih W, Coats DW (2000) Infection of Gymnodinium sanguineum by the dinoflagellate Amoebophrya sp.: effect of nutrient environment on parasite generation time, reproduction, and infectivity. J Eukaryot Microbiol 47:504-510

Submitted: April 9, 2001; Accepted: July 5, 2001 Proofs received from author(s): February 4, 2002 